\title{
Recent patents in angiogenesis research
}

\begin{tabular}{ll} 
Patent \# & Subject \\
\hline EP 943679 & $\begin{array}{l}\text { A new RNase-like protein useful for treating cancer and } \\
\text { promoting angiogenesis and wound healing. }\end{array}$ \\
WO 9942606 & $\begin{array}{l}\text { Use of teleosts as animal models, for use in screening for } \\
\text { agents with angiogenesis, cell death, or toxin activity. }\end{array}$ \\
WO 9942486 & $\begin{array}{l}\text { Production of endostatin, an angiogenesis inhibitor, by } \\
\text { refolding recombinant protein; useful as an anticancer } \\
\text { and antimetastatic agent. }\end{array}$ \\
WO 9942461 & $\begin{array}{l}\text { Treating chemokine-mediated diseases using new and } \\
\text { known quinoxaline derivatives with antinflammatory and } \\
\text { antiangiogenic activity. }\end{array}$ \\
WO 9942436 & $\begin{array}{l}\text { New matrix metalloproteinase-inhibiting N-hydroxyamide } \\
\text { derivatives used for treating cancer and inflammatory, } \\
\text { cardiovascular, ocular, and gastrointestinal diseases. }\end{array}$ \\
WO 9942137 & $\begin{array}{l}\text { A new method for gene therapy using heterologous gene } \\
\text { sequences under the control of a promoter from a heat- } \\
\text { inducible gene, including a composition comprising a gene } \\
\text { sequence specifying an antiangiogenesis-inducing protein } \\
\text { such as angiostatin or endostatin. }\end{array}$
\end{tabular}

WO 9942120 A new extracellular serine protease for the diagnosis of neoplastic disease, particularly breast and ovarian carcinomas.

WO 9941412 A new nucleic acid encoding NPG-1 protein, used to treat and diagnose cancer, particularly of the prostate.

WO 9940947 Angiogenesis-targeting molecules for the detection and treatment of cancer.

WO 9940945 Targeted gene expression by intra-arterial injection of a vector together with vasoactive agent, particularly for inducing angiogenesis, as in cases of myocardial ischemia. This method provides high-level, sustained transgene expression in the myocardium.

WO 9940193 A human angiopoietin homolog, ZAPO3, useful for the study and regulation of angiogenesis. ZAPO3 can be used in methods to stimulate cell growth and tissue development, and may be involved in the modulation of endocrinevascular cell association.

WO 9940118 Monoclonal antibodies that react specifically with human vascular endothelial growth factor (VEGF) receptor KDR but not with human VEGF receptor FIt-1, for the treatment of solid tumor proliferation.

WO 9939702 Use of an angiogenesis inhibitor to regulate the size and/or growth of normal vascularized tissue, for the treatment of obesity.

JP 11201966 VEGF/VPF inhibitor screening method; useful for the diagnosis of cancer and angiogenesis.

WO 9937314 Products comprising a carotenoid-bearing lipid, isolated from sea cucumber, for use as dietary supplements for the treatment of dermatitis and cancer. Products are lipoxygenase and angiogenesis inhibitors.

Assignee
Innogenetics NV
(Zwijndrecht, Belgium)
Phylonix Pharmaceuti-
cals (Cambridge, MA)
G.D. Searle \& Co.
(Skokie, IL)
Warner Lambert
(Morris Plains, NJ)
American Cyanamid
(Wayne, NJ)

Bromley P

Author

Date

9/22/1999

Status

$-$

Frost D, Semino C,

$8 / 26 / 99$

Serbedzija GN

Harding El,

Violand BN

$8 / 26 / 99$

A1

Connor DT, Li, JJ,

8/26/99

Roth BD, Trivedi BK

Baker JL, Davis JM, 8/26/99

Venkatesan AM

Bromley P

$8 / 26 / 99$

A2

Univ. of Arkansas

(Fayetteville, AR)

Beth Israel

Deaconess Med.

Center (Boston, MA)

Resolution Pharmaceuticals (Mississauga ON, Canada)

O'Brien TJ,

8/26/99

A1

Tanimoto $\mathrm{H}$

Sytkowski A,

8/19/1999 Yang $M$

Eshima D,

8/19/1999

A2

Regents of the Univ. of California

(Oakland, CA)

\section{ZymoGenetics (Seattle, WA)}

Holloway JL, Shoemaker KE

8/12/1999

Pollak A, Thornback J

Hammond HK

8/19/1999
Kyowa Hakko

Kogyo (Tokyo)

Children's Med. Center; Mass. Inst. of Technology (Cambridge, MA)

Toa Gosei (Tokyo)

Collin PD
Anazawa $\mathrm{H}$,

Hanai N, Ito M,

Shibuya M, Shinkai

A, Shitara K

Folkman J,

Langer RS,

Rupnick M 